\title{
Kopolimerisasi Grafting Campuran N-Isopropilakrilamida dan Glisidil Metakrilat pada Film Polietilen yang Diinduksi oleh Sinar Ultraviolet
}

\author{
Irwan Ginting Suka \\ Jurusan Kimia, Fakultas Matematika dan Ilmu Pengetahuan Alam, Universitas Lampung, \\ Jl. Sumantri Brojonegoro No. 1 Bandar Lampung, 35144 \\ Diterima 02-11-2007Ｄisetujui 18-03-2008
}

\begin{abstract}
Liquid phase ultraviolet irradiation was used to graft the mixtures of $\mathrm{N}$-isopropylacrylamide and glycidyl methacrylate to a linear low-density polyethylene film (thickness of $30 \mathrm{~m}$ ) surface. Xanthone was used as photoinitiator, which was coated on the film surface earlier. The surface of the grafted polyethylene samples were characterized by attenuated total-reflection IR spectroscopy and scanning electron microscopy. Elemental analysis indicated that the NIPAAm fraction with respect to GMA in the graft copolymer increased with increasing NIPAAm ratio in the comonomer feed solution. The reactivity ratios of NIPAAm and GMA monomers determined in the present graft copolymerization system were found to be $0,31 \pm 0,1$ and $4,8 \pm 0,2$, respectively. It was found that the epoxy groups of GMA-grafted chains in the NIPAAm/GMA-grafted films have the ability to react with ethylenediamine (En). The aminated NIPAAm/GMA-grafted film had an excellent ability to adsorb cupric ion. The temperature-responsive character of the resulting grafted films was evaluated by measuring the water absorbency of the grafted NIPAAm/ GMA when immersed in water and/or methanol at 5 to $50^{\circ} \mathrm{C}$.
\end{abstract}

Keywords: absorption of cupric ion, glycidyl methacrylate, $\mathrm{N}$-isopropylacrylamide, photografting, temperatureresponsive character

\section{PENDAHULUAN}

Polimer dengan sifat-sifat psikokimia spesifik seperti komposisi kimia, hidrofilitas, kekasaran, kekristalan, daya hantar listrik, daya adhesi, dan kelumasan sangat dibutuhkan untuk pemanfaatan polimer tersebut (Chan 1994). Dari penelusuran literatur diketahui berbagai upaya telah dilakukan untuk memodifikasi permukaan polimer agar memiliki sifatsifat psikokimia tersebut di atas. Salah satu metoda yang diketahui efisien dan efektif untuk tujuan tersebut adalah fungsionalisasi polimer, pemberian gugus fungsi tertentu yang berperan sebagai pembawa sifat baru pada polimer yang dimodifikasi, dengan teknik grafting (penempelan/pencangkukan). Modifikasi polimer dengan teknik grafting melibatkan pembentukan situs aktif berupa radikal bebas atau ion terlebih dahulu pada polimer induk. Pembentukan situs aktif pada polimer induk dapat dilakukan dengan dua cara, yakni metode kimia dan metode fisika. Dengan metode kimia, radikal terbentuk pada $P E$ akibat abstraksi atom hidrogen oleh radikal inisiator seperti BPO (dibenzoyl peroxide), AIBN (azobisisobutyronitrile), atau bahan pengoksidasi seperti garam cerium (Moad et al, 2002). Pembentukan situs aktif dengan metode fisika dapat dilakukan dengan berbagai cara, meliputi radiasi laser (Saito et al, 1997), elektron beam (He \& Gu 2003), ion beam (Koh et al, 1995), plasma dan radiasi sinar- $\gamma$ (El-Sawy \& Sagheer, 2001) korona dan sinar UV (Yang \& Ranby 1996) terhadap polimer induk untuk menghasilkan radikalradikal yang mampu untuk menginisiasi reaksi grafting.

Beberapa jenis monomer vinil yang umum digunakan untuk memodifikasi berbagai polimer dengan teknik grafting, antara lain adalah maleat anhidrid (Liu et al, 2003), glisidil metakrilat (Pesneau et al, 2004), metil metakrilat (Zhao et al, 2003), N-isopropilakrilamida (Huang et al, 2003), asam akrilat (Irwan et al, 2004a), dan campuran dua monomer (Chun et al, 1999; Hegazy et al, 2001; Suh et al, 2002). Pemanfaatan monomermonomer turunan akrilat seperti disebutkan di atas sebagai monomer penggrafting didasarkan pada kemudahannya berpolimerisasi dan tersedia di pasaran dengan harga yang murah. Pada penelitian sebelumnya, film polietilen (PE) telah dimodifikasi dengan memasukkan berbagai fungsionalitas tunggal seperti kepekaan terhadap suhu (Irwan et al, 2002a; Irwan 2006b), pH (Irwan et al, 2002b), sifat katalis (Aoyama et al, 2001; Hashimoto et al, 2003), amobilisasi enzym (Aoyama et al, 2001) dan penukar 
ion (Irwan, 2006a) dengan menggunakan teknik grafting (penempelan/pencangkukan) yang diinduksi oleh sinar ultraviolet $(\lambda>290 \mathrm{~nm})$. Berbagai faktor yang mempengaruhi proses grafting juga telah dilakukan antara lain seperti pengaruh konsentrasi monomer dan inisiator, waktu dan suhu polimerisasi grafting, pelarut organik baik untuk monomer hidrofilik maupun hidrofob.

Dalam penelitian ini dilakukan grafting campuran monomer vinil yakni $\mathrm{N}$-isopropilakrilamida (NIPAAm) dan Glisidil Metakrilat (GMA) ke film PE dengan bantuan xanthone (XT) sebagai fotoinisiator yakni inisiator yang akan mengalami eksitasi akibat menyerap sinar ultraviolet (UV). Poli NIPAAm adalah suatu polimer yang memiliki kepekaan terhadap suhu disekitar suhu kritis larutannya (Lower Critical Solution Temperature, LCST) yakni disekitar $32^{\circ} \mathrm{C}$ (Tanaka et al, 1995). Hidrogel dengan struktur sambung silang dari poli NIPAAm dalam larutan berair akan mengalami penggembungan (swelling) dan pengkerutan (shrinking) di bawah dan di atas suhu LCST tersebut. Sifat ini disebabkan oleh pemutusan - pembentukan reversibel dari ikatan hidrogen antara gugus $\mathrm{NH}$ atau $\mathrm{C}=\mathrm{O}$ dalam rantai poli NIPAAM dengan molekul air sekelilingnya dengan adanya sedikit perubahan suhu larutan (Leie et al, 1997). Disamping itu, glisidil metakrilat adalah suatu monomer yang sangat menarik disebabkan memiliki dua sifat fungsional yang unik yakni ikatan rangkap yang reaktif terhadap pembentukan radikal bebas, dan gugus epoksi yang dapat bereaksi cepat dengan sejumlah gugus fungsi lain seperti karboksil (Zou et al, 2001), hidroksil (Kim et al, 1991), posfat (Pesneau et al, 2004), amina (Yu \& Ryu 1999) dan lainnya (Choi et al, 2003). Struktur molekul monomer NIPAAm, GMA dan inisiator xanthone diperlihatkan oleh

\section{Gambar 1.}

Polimerisasi grafting campuran monomer vinil seperti NIPAAm dan GMA (NIPAAm/GMA) pada film $\mathrm{PE}$, sangat menarik karena berbagai tipe rantai polimer dengan gugus fungsi yang berbeda yakni sifat peka suhu dan gugus reaktif epoksi dapat digrafting ke dalam

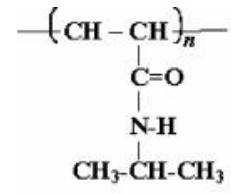

(a)

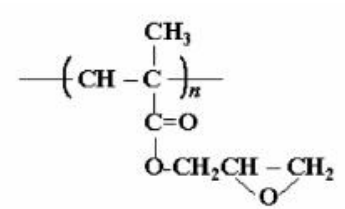

(b)

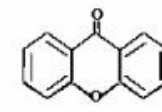

(c)
Gambar 1. Struktur molekul (a) N-isopropilakrilamida, (b) Glisidil metakrilat dan (c) Xanthone struktur polimer induk film PE. Film PE yang tergrafting dengan campuran NIPAAm dan GMA dikarakterisasi dengan menggunakan spektroskopi ATR-IR ( Attenuated Total Reflection Infrared) dan SEM (Scanning Electron Microscopy).

\section{METODE PENELITIAN}

Material. Film polietilen (PE) yang digunakan adalah PE komersial kerapatan rendah (LLDPE) dengan ketebalan $30 \mathrm{~m}$ dan ukuran $3 \times 10 \mathrm{~cm}$. Film PE direfluks dengan aseton selama 24 jam pada suhu $60^{\circ} \mathrm{C}$ lalu dikeringkan. Film PE dicelupkan dalam larutan fotoinisiator, yang terdiri dari xanthone (XT) $(0,1 \%$ berat) yang dilarutkan bersama-sama dengan polivinil asetat $(B M=100)(0,5 \%$ berat) dalam aseton. Setelah dicelup lebih kurang sepuluh detik, film lalu diangkat dari larutan dan dikeringkan dalam vakum untuk mendapatkan PE film yang telah dilapisi dengan fotoinisiator. GMA dimurnikan dari zat penstabilnya dengan destilasi vakum (4 torr, $35^{\circ} \mathrm{C}$ ). NIPAAm dimurnikan dengan rekristalisasi dalam campuran benzen $/ n$-hexane $(50 / 50 \mathrm{w} / \mathrm{w})$. XT, etilen diamin, dan metil etil keton merupakan bahan dengan kualitas sintesis.

Fotografting. Fotografting dilakukan dalam tabung polimerisasi (Pyrex) yang telah diisi dengan film PE yang telah dilapisi dengan fotoinisiator, $30 \mathrm{ml}$ air, monomer campuran GMA dan NIPAAm (NIPAAm/GMA) dengan perbandingan tertentu (konsentrasi total monomer $=0,47 \mathrm{~mol} / \mathrm{l})$. Tabung polimerisasi divakumkan dan dialiri gas nitrogen secara berselangseling, kemudian ditutup dengan rapat. Tabung polimerisasi lalu disinari dengan lampu ultra violet (UV) dengan panjang gelombang $>300 \mathrm{~nm}$ (high-pressure mercury lamp $(400 \mathrm{~W})$ pada suhu $60^{\circ} \mathrm{C}$ dengan menggunakan Riko Rotary Photochemical Reactor (RH400-10W, Riko Kagaku Sangyo Co., Ltd, Chiba, Japan). Pyrex glass yang digunakan sebagai tabung polimerisasi dalam penelitian ini, meneruskan cahaya pada $\lambda>290 \mathrm{~nm}$. Absorbsi fotoinisiator xanthone terhadap sinar ultraviolet adalah maksimum pada 250 $-350 \mathrm{~nm}$, sehingga fotoinisiator dapat mengabsorbsi cahaya dengan efisien dalam sistem polimerisasi yang digunakan.

Setelah reaksi polimerisasi grafting di atas, film PE lalu diambil dari tabung polimerisasi kemudian diekstraksi dengan air dingin selama 48 jam kemudian dengan metil etil keton selama 24 jam, untuk 
menghilangkan homopolimer yang terbentuk disekeliling film PE dan monomer NIPAAm dan GMA yang tidak bereaksi. Persen grafting ditentukan berdasarkan perbandingan berat rantai grafting NIPAAm/GMA pada film PE dengan berat awal PE film sebelum digrafting:

$$
\text { Persen grafting }(\%)=\frac{\text { berat rantai grafting }}{\text { berat awal film PE }} \times 100
$$

Pengukuran ATR-IR (Attenuated Total Reflection-Infrared). Permukaan film PE yang belum dan yang telah digrafting dengan NIPAAm/GMA dikarakterisasi dengan spektroskopi inframerah (automatic infrared microscope,AIM-800, FTIR-8700 from Shimadzu Co., Ltd. Kyoto, Japan). Rantai graft NIPAAm dan GMA pada permukaan PE film dinyatakan dari pita serapan gugus amida NIPAAm pada $1640 \mathrm{~cm}$ ${ }^{1}$ dan gugus karbonil (stretching) GMA pada $1728 \mathrm{~cm}^{-1}$.

Pengukuran SEM (Scanning Electron Microscope). Profil distribusi logam Cu dalam sayatan melintang (cross-section) dari film PE tergrafting NIPAAm/GMA yang telah diaminasi dengan etilendiamin diukur dengan SEM (JSM-5600LV, JED-2200), JEOL Co., Ltd. Tokyo, Japan.

Reaksi Dengan Etilendiamin (En). Film PE yang telah digrafting NIPAAm/GMA dengan berat tertentu dicelupkan ke dalam larutan $30 \mathrm{ml}$ dimetilformamida (DMF) yang mengandung En lalu reaksi dilangsungkan pada $70^{\circ} \mathrm{C}$ selama 3 jam. Setelah reaksi, film PE lalu diangkat dari larutan kemudian dicuci dengan DMF dan dihitung jumlah En yang bereaksi dengan gugus epoksi pada NIPAAm/GMA menggunakan analisis elementer (metoda Kjel Dhal). Kandungan En yang terikat pada gugus epoksi NIPAAm/GMA dihitung berdasarkan perbandingan jumlah En yang terikat dibandingkan terhadap jumlah awal gugus epoksi NIPAAm/GMA. Kandungan En $(\mathrm{mol} \%)=$

$$
\frac{\text { jumlah En yang bereaksi }}{\text { jumlah gugus epoksi semula }} \times 100
$$

Pengukuran Kemampuan Adsorpsi ion $\mathrm{Cu}^{2+}$. Film PE tergrafting NIPAAm/GMA yang telah diaminasi dengan berat tertentu dicelupkan ke dalam $40 \mathrm{ml}$ larutan buffer (Clark-Lubs, $\mathrm{pH}=5,5$ ) yang mengandung ion logam $\mathrm{Cu}^{2+}$ sebanyak $0,179 \mathrm{~mol} / \mathrm{l}$. Pada penelitian lain disebutkan bahwa, jumlah maksimum ion $\mathrm{Cu}^{2+}$ yang dapat diadsorbsi oleh gugus piridin tergrafting film PE (El-Sayed et al, 1997) dan gugus asam karboksilat tergrafting selulosa (Güclü et al, 2003) adalah pada pH sekitar 5 , oleh karena itu dalam penelitian ini untuk mengadsorbsi ion $\mathrm{Cu}^{2+}$ juga dilakukan pada $\mathrm{pH}$ sekitar 5. Reaksi adsorpsi ion $\mathrm{Cu}^{2+}$ oleh film PE tergrafting NIPAAm/GMA yang telah diaminasi, dilakukan pada $25^{\circ} \mathrm{C}$ selama 24 jam. Setelah reaksi, film diangkat dari larutan dan konsentrasi ion $\mathrm{Cu}^{2+}$ dalam larutan dihitung kembali dengan metode titrasi kelat (Islam et al., 1992), menggunakan larutan standar EDTA dan indikator (2piridilazo)-2-naphthol.

Pengukuran Daya Absorbsi Air atau Metanol. Polietilen film tergrafting NIPAAm/GMA dengan berat $\mathrm{W}_{1}$, dicelupkan ke dalam larutan air atau metanol dengan suhu bervariasi 5 hingga $50^{\circ} \mathrm{C}$. Setelah perendaman, $\mathrm{PE}$ film diangkat dari larutan, sisa pelarut pada permukaan film dikeringkan dengan kertas saring, berat film tersebut diukur kembali, $\mathrm{W}_{2}$. Daya serap air atau metanol dihitung dari perbandingan selisih berat film PE tergrafting NIPAAm/GMA setelah dan sebelum direndam dalam air atau metanol terhadap berat film PE sebelum digrafting dengan NIPAAm/GMA, $W_{0}$, dengan rumus berikut:

$$
\text { Daya serap air }(\%)=\frac{W_{2}-W_{1}}{W_{0}} \times 100
$$

\section{HASIL DAN PEMBAHASAN}

Sifat Grafting. Grafting dengan bantuan sinar UV $(\lambda>300 \mathrm{~nm})$ yang lebih umum dikenal dengan istilah fotografting, telah diketahui merupakan suatu metode yang efektif untuk fungsionalisasi berbagai polimer material (Yang \& Ranby 1996; Ambrosio et al, 1997; Yu \& Ryu 1999; Deng et al, 2000; Wang \& Brown, 2004; Irwan \& Wasinton 2007). Radiasi sinar UV-dekat umumnya tidak diserap oleh sebagian besar hidrokarbon polimer akan tetapi terserap dengan baik oleh inisiator (penginisiasi) seperti Xanthone (XT), benzophenon, kuinon dan turunannya (Yang \& Ranby 1996; Irwan et al, 2002b). Fotoinisiator XT yang tereksitasi oleh radiasi UV akan mengabstraksi atom hidrogen dari film PE dan menghasilkan radikal polietilen. Radikal polimer yang terbentuk ini merupakan situs aktif yang akan menginisiasi reaksi grafting (penempelan/ pencangkukan) NIPAAm dan/atau GMA ke film PE. Pada saat yang bersamaan, bila XT tereksitasi mengabstraksi atom hidrogen dari monomer, maka akan terbentuk homopolimer di dalam sistem polimerisasi grafting. Efisiensi proses ini bergantung pada beberapa faktor seperti kemampuan fotoinisiator terurai akibat sinar ultraviolet (photolysis), jumlah 


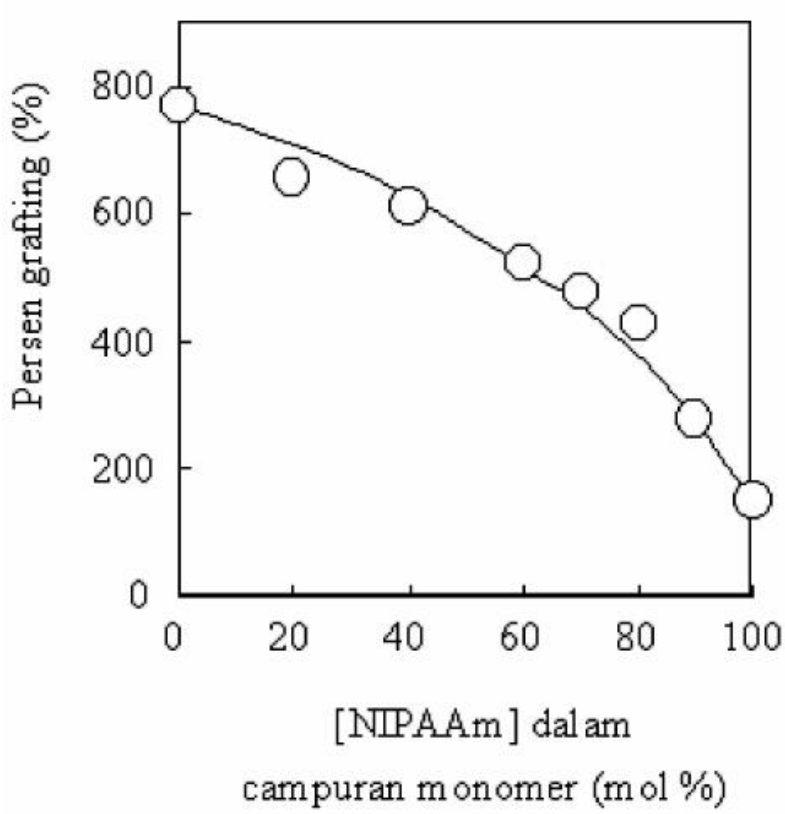

Gambar 2. Kopolimerisasi grafting N-isopropilakrilamida/glisidill metakrilat pada film polietilen terlapis xanthone pada $60^{\circ} \mathrm{C}$ selama 60 menit. [Total monomer] = $0.47 \mathrm{~mol} / \mathrm{L},[\mathrm{XT}]=0.1 \mathrm{wt} . \%$

radikal bebas yang terbentuk tiap molekul fotoinisiator, kemampuan radikal-radikal yang terbentuk berdiffusi ke dalam struktur polimer dan reaktifitas fotoinisiasiator terhadap polimer untuk mengabstraksi atom hidrogen untuk membentuk situs grafting (Yang \& Ranby 1996). Gambar 2 memperlihatkan hasil grafting monomer campuran NIPAAm/GMA ke film PE yang diinduksi oleh sinar ultraviolet pada $60^{\circ} \mathrm{C}$. Persen grafting adalah jumlah NIPAAm/GMA yang tergrafting (tertempel/ tercangkuk) ke film PE.

Persen grafting, yakni jumlah NIPAAm/GMA yang tergrafting pada film $P E$, semakin menurun dengan meningkatnya konsentrasi NIPAAm dalam campuran NIPAAm/GMA. Hasil Gambar 2 ini memberikan gambaran bahwa pada reaksi polimerisasi grafting ke PE, dalam campuran NIPAAm/GMA, GMA lebih reaktif dibandingkan NIPAAm. Gambar 3 memperlihatkan komposisi NIPAAm dalam rantai grafting NIPAAm/GMA meningkat seiring dengan meningkatnya konsentrasi NIPAAm dalam komposisi campuran NIPAAm/GMA.

Dengan menggunakan metoda Fineman-Ross, dari data Gambar 2 diperoleh perbandingan kereaktifan monomer (monomer reactivity ratio) NIPAAm $\left(r_{1}\right)$ dan $\left(r_{2}\right)$ GMA masing-masing adalah $0,31 \pm 0,1$ dan $4,8 \pm 0,2$. Hasil ini hampir mirip dengan hasil kopolimerisasi NIPAAm/GMA dalam dioksan terdeuterasi pada $70^{\circ} \mathrm{C}$, yakni $r_{1}=0,39$ dan $r_{2}=2,69$ (Virtanen \& Tenhu 2001). Lebih besarnya perbandingan kereaktifan monomer

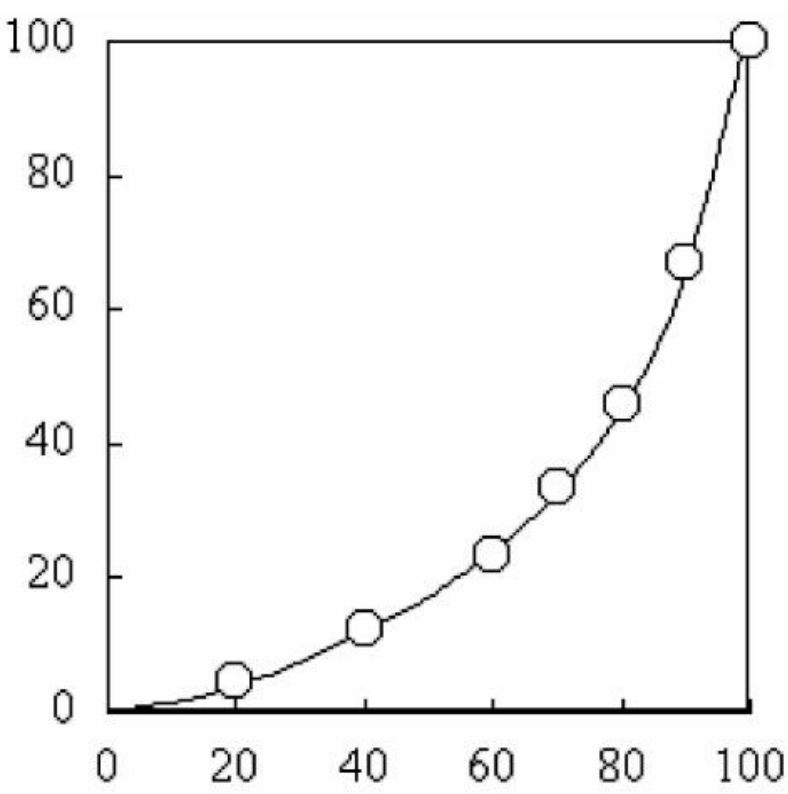

Gambar 3. Komposisi nitrogen $\mathrm{N}$-isopropilakrilamida hasil kopolimerisasi grafting $\mathrm{N}$-isopropilakrilamida/ glisidil metakrilat pada film polietilen terlapis xanthone pada $60^{\circ} \mathrm{C}$ selama 60 menit. [Total monomer $]=0.47 \mathrm{~mol} / \mathrm{L},[X T]=0.1 \mathrm{wt} . \%$

GMA dibandingkan NIPAAm, merupakan lebih besarnya reaktifitas GMA dibandingkan NIPAAm terhadap fim polietilen.

Pengukuran ATR-IR (Attenuated Total Reflection-Infrared). Untuk mengetahui distribusi rantai grafting NIPAAm dan GMA pada permukaan film PE, sampel film PE, film PE tergrafting NIPAAm (48\%), film PE tergrafting NIPAAm (58\%) dan film PE tergrafting NIPAAm/GMA (persen grafting $=87 \%$ ) dianalisis dengan spektroskopi inframerah (ATR-IR), dan hasilnya diperlihatkan pada Gambar 4. Pada spektrum (a) terdapat puncak karakteristik dari gugus metilen dari polietilen pada $1470 \mathrm{~cm}^{-1}$ dari $\mathrm{CH}_{2(\text { bend) }}$. Pada film PE tergrafting NIPAAm pita-pita serapan di atas digantikan oleh serapan kuat gugus amida, $\mathrm{CONH}$ pada 1640 dan $1550 \mathrm{~cm}^{-1}$ (Kubota \& Shiobara 1998).

Pada film PE tergrafting GMA, muncul pita serapan gugus karbonil asam metakrilat $\mathrm{C}=\mathrm{O}_{\text {(strech) }}$, pada 1728 $\mathrm{cm}^{-1}$ dan gugus epoksi pada 906 dan $845 \mathrm{~cm}^{-1}$ (Irwan et al, 2004b). Pita-pita serapan di atas, muncul seluruhnya pada film PE tergrafting NIPAAm/GMA. Hal ini mengindikasikan kedua komponen NIPAAm/GMA telah tergrafting pada lapisan permukaan film $\mathrm{PE}$.

Pengukuran SEM (Scanning Electron Microscope). Untuk konfirmasi hasil analisis ATR-IR pada permukaan film $\mathrm{PE}$, karakterisasi pada garis sayatan melintang (searah dengan tebal film PE) dari film PE tergrafting NIPAAm/GMA dengan menggunakan 


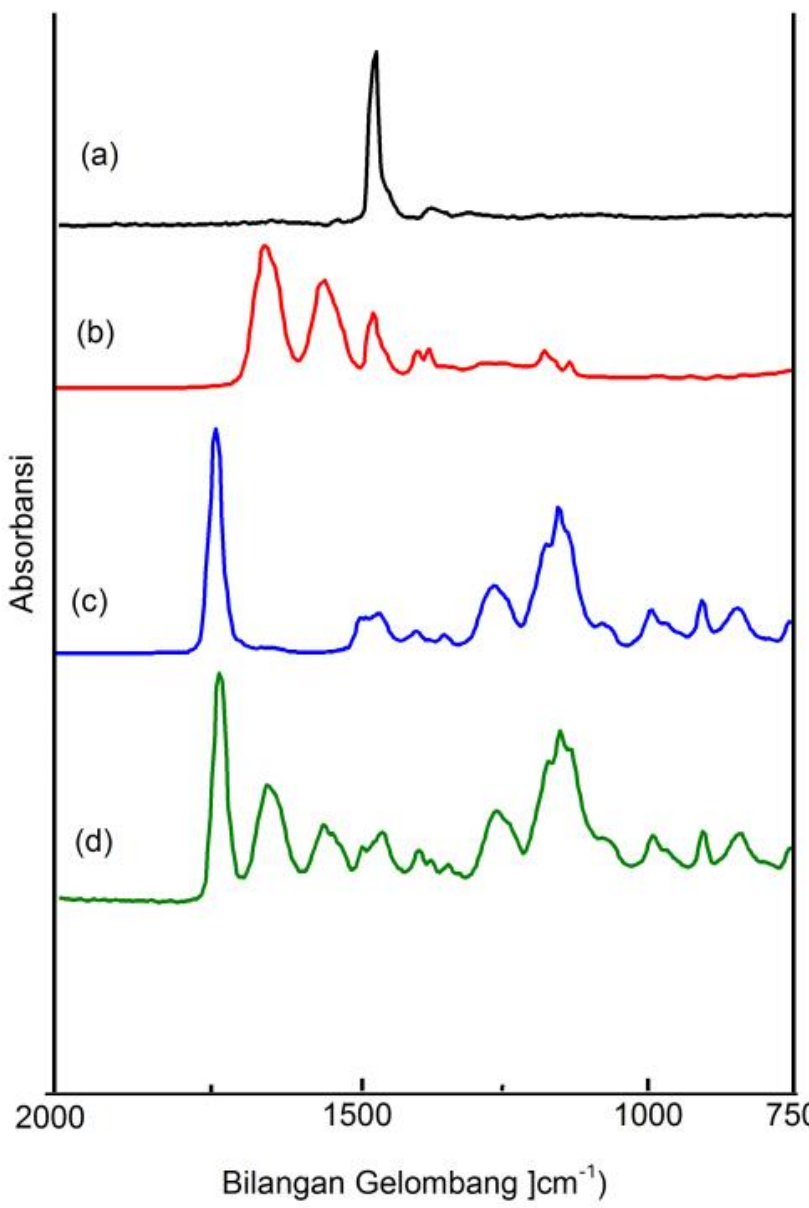

Gambar 4. Spektrum ATR-IR dari (a) Film polietilen, (b) Film polietilen tergrafting $\mathrm{N}$-isopropilakrilamida (NIPAAm), $48 \%$ (c) Film polietilen tergrafting glisidil metakrilat (GMA), $58 \%$ (d) Film polietilen tergrafting NIPAAm/GMA, $87 \%$

SEM, hasilnya diperlihatkan pada Gambar 5. Sampel yang digunakan adalah film PE tergrafting NIPAAm/ GMA dengan persen grafting 68\% (komposisi monomer NIPAAm : GMA adalah $8: 2$ ). Distribusi rantai NIPAAm atau GMA searah dengan tebal film PE ini dapat diketahui melalui profil distribusi logam paladium $(\mathrm{Pd})$ untuk film PE tergrafting NIPAAm dan distribusi $\mathrm{Cu}^{2+}$ dari hasil rantai GMA teraminasi yang telah membentuk kompleks dengan ion $\mathrm{Cu}^{2+}$.

Arah vertikal mewakili konsentrasi relatif dari atom $\mathrm{Pd}$ dan ion $\mathrm{Cu}^{2+}$ sedangkan arah horizontal adalah arah (a)

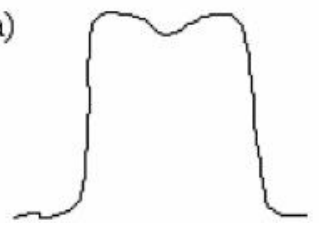

(b)

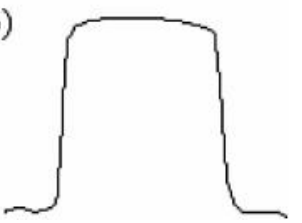

Gambar 5. Profil distribusi (a) atom paladium dan (b) ion $\mathrm{Cu}^{2+}$ dalam sayatan melintang (cross-section) dari film PE tergrafting NIPAAm/GMA dengan persen grafting $68 \%$

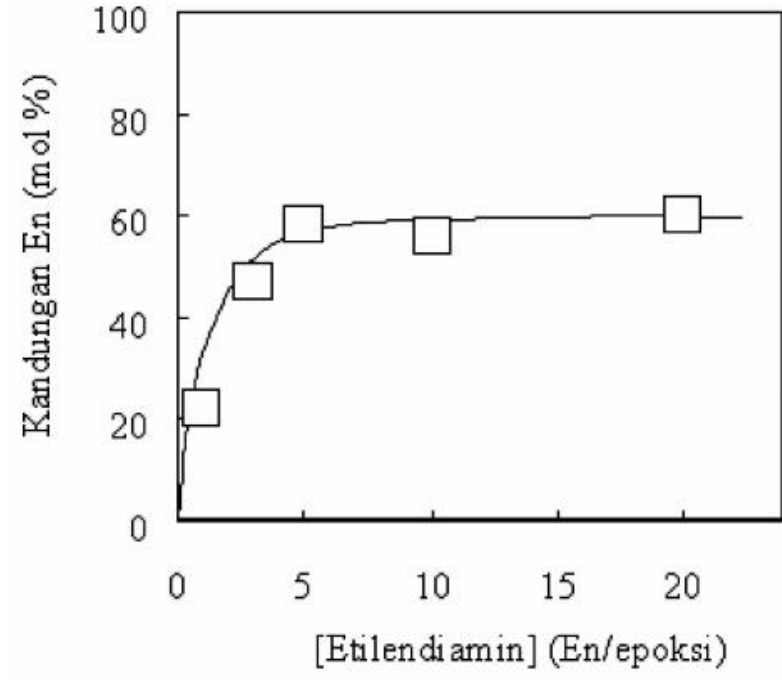

Gambar 6. Reaksi film PE tergrafting NIPAAm/GMA dengan etilendiamin dalam $\mathrm{N}, \mathrm{N}^{*}$-dimethylformamide pada $70^{\circ} \mathrm{C}$ selama 3 jam. Persen grafting $=94 \%$

sayatan melintang dari film PE. Dari Gambar 5 terlihat bahwa rantai grafting NIPAAm dan GMA terdiffusi sampai ke bagian dalam/tengah dari film PE, sehingga terjadi pertemuan dari rantai grafting dari sisi-sisi berlawanan yang menghasilkan rantai grafting NIPAAm dan GMA terdistribusi dengan homogen dalam film.

Reaktifitas Terhadap Amina. Gugus epoksi glisidil metakrilat diketahui dapat bereaksi cepat dengan sejumlah gugus fungsi lain seperti karboksil (Zou et al, 2001), hidroksil (Kim et al, 1991), posfat (Pesneau et al, 2004), amina (Yu \& Ryu 1999) dan lainnya (Choi et al, 2003). Dalam penelitian ini gugus epoksi dari film PE tergrafting NIPAAm/GMA diuji reaktifitasnya terhadap senyawaan amina (etilendiamin, En) yang dilakukan dalam $\mathrm{N}, \mathrm{N}^{\prime}$-dimethylformamide pada $70^{\circ} \mathrm{C}$ selama 3 jam, hasilnya diperlihatkan dalam Gambar 6.

Arah mendatar dalam gambar merupakan konsentrasi En dalam sistem, yang bervariasi dari 5 sampai 20 kali lipat dari konsentrasi gugus epoksi dalam film PE tergrafting NIPAAm/GMA. Jumlah En yang terikat pada film PE tergrafting GMA semakin besar dengan meningkatnya konsentrasi En yang digunakan dalam sistem. Kecendrungan yang sama juga diperlihatkan bila reaksi dilakukan selama 24 jam. Hal ini menunjukkan bahwa gugus epoksi dari NIPAAm/ GMA yang tergrafting pada film PE masih menunjukkan reaktifitas terhadap amin.

Kemampuan Adsorpsi ion $\mathrm{Cu}^{2+}$. Gugus amina dari residu En yang terikat pada gugus epoksi dari film PE tergrafting NIPAAm/GMA diharapkan dapat 
membentuk kompleks dengan ion-ion logam. Dalam penelitian ini diuji reaktifitas dari gugus amin dalam pembentukan kompleks dengan ion $\mathrm{Cu}^{2+}$ dan hasilnya diperlihatkan dalam Gambar 7. Jumlah ion $\mathrm{Cu}^{2+}$ yang teradsorbsi dinyatakan dalam jumlah ion $\mathrm{Cu}^{2+}$ teradsorbsi per satu mol residu En di dalam sampel.

Angka 0,5 pada arah vertikal dari Gambar 7 mengimplikasikan jumlah En yang dibutuhkan untuk membentuk kompleks dengan $\mathrm{Cu}^{2+}$, yakni sekitar 2 . Jumlah ion $\mathrm{Cu}^{2+}$ yang teradosrpsi pada En hasil aminasi gugus epoksi film PE tergrafting NIPAAm/GMA, meningkat dengan semakin bertambahnya konsentrasi $\mathrm{Cu}^{2+}$ yang digunakan dan mencapai maksimum sekitar 0,4 yakni pada penggunaan ion $\mathrm{Cu}^{2+}$ sekitar $10 \mathrm{mmol} /$ I. Secara umum, film PE tergrafting NIPAAm/GMA yang telah diaminasi dengan En menunjukkan kemampuan yang baik untuk mengadsorpsi ion $\mathrm{Cu}^{2+}$.

Kepekaan Terhadap Suhu dari Film PE tergrafting NIPAAm/GMA. Kepekaan terhadap suhu dari film PE tergrafting dengan NIPAAm/GMA, dilihat dari daya serap air dari film tersebut di dalam air dan metanol dengan suhu 5 hingga $50^{\circ} \mathrm{C}$ (Kubota \& Shiobara 1998; Irwan 2006b), dan hasilnya diperlihatkan pada Gambar 8. Persen grafting sampel film PE tergrafting NIPAAm/ GMA yang digunakan adalah $94 \%$, diperoleh dari hasil polimerisasi grafting NIPAAm : GMA $=8: 2$ pada polietilen film.

Daya serap air dan metanol film PE tergrafting NIPAAm/GMA, menurun dengan meningkatnya suhu larutan dan terjadi penurunan tajam disekitar suhu 20 hingga $30^{\circ} \mathrm{C}$, yakni disekitar suhu kritis larutan poli NIPAAm. Daya absorbsi film PE tergrafting NIPAAm/ GMA terhadap metanol lebih besar dibandingkan terhadap air, hal ini disebabkan metanol lebih mampu membasahi rantai poliNIPAAm dibandingkan air (Tanaka et al, 1995). Hal ini menunjukkan bahwa film PE tergrafting NIPAAm/GMA masih menunjukkan sifat peka suhu lingkungan sebagai hasil kerja dari rantai grafting poliNIPAAm.

\section{KESIMPULAN}

Berdasarkan uraian di atas, dapat disimpulkan bahwa polietilen (PE) dengan dua fungsional yang berbeda yakni sifat peka suhu dan gugus reaktif epoksi dapat diperoleh dengan menggunakan metode fotografting. Rantai grafting poli NIPAAm dan poli GMA

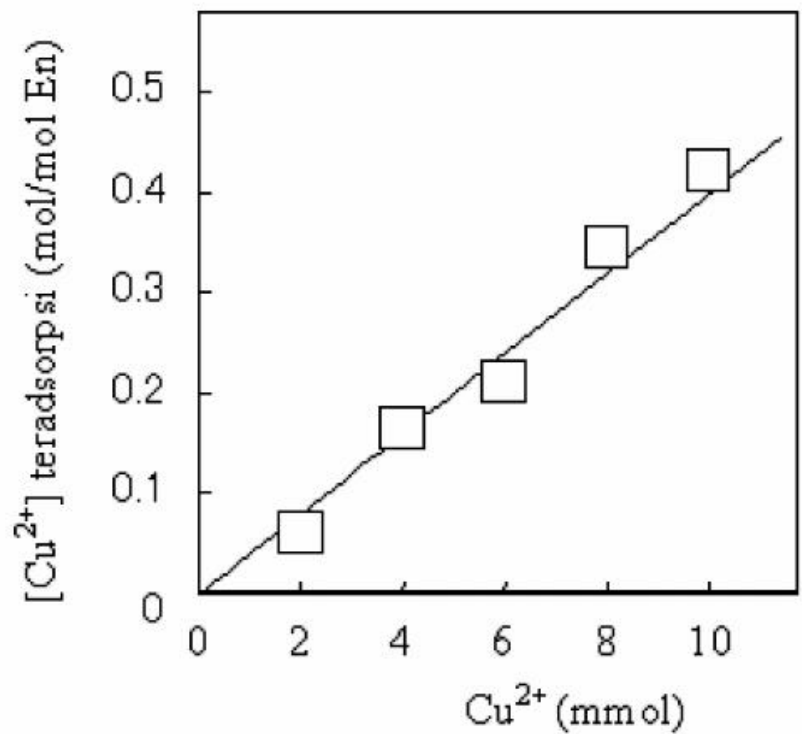

Gambar 7. Adsorpsi ion $\mathrm{Cu}^{2+}$ oleh En hasil aminasi gugus epoksi film PE tergrafting NIPAAm/GMA. Adsorpsi dilakukan pada: $\mathrm{pH}=5$, suhu $25^{\circ} \mathrm{C}$ selama 24 jam

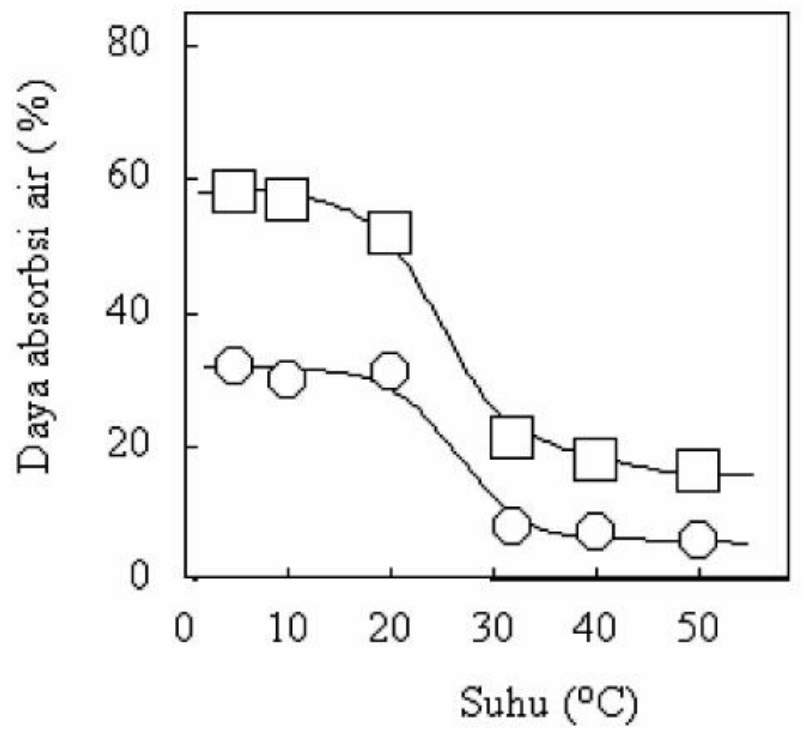

Gambar 8. Daya absorbsi film polietilen tergrafting NIPAAm/GMA dalam pelarut $(O)$ air dan ( ) metanol. Persen grafting $=94 \%($ NIPAAm $:$ GMA $=8: 2)$

pada polietilen tergrafting NIPAAm/GMA terdistribusi secara homogen dalam substrat polietilen. Film PE tergrafting NIPAAm/GMA yang diperoleh, memperlihatkan reaktifitas untuk dapat bereaksi dengan etilen diamin (En) dan memiliki sifat peka suhu lingkungannya. Atom nitrogen yang terdapat dalam film PE tergrafting NIPAAm/GMA yang telah diaminasi dapat dimanfaatkan untuk membentuk kompleks dengan ion $\mathrm{Cu}^{2+}$. Sifat peka suhu lingkungan film PE tergrafting NIPAAm/GMA terjadi disekitar suhu kritis larutan poli NIPAAm. 
UCAPAN TERIMA KASIH

Penulis mengucapkan terima kasih seluruh yang ikut berpartisipasi memberikan bantuan dalam penyelesaian penelitian ini.

\section{DAFTAR PUSTAKA}

Ambrosio, A. D., Rebulla, P., Revelli, N., Morelati, F., Marangoni, F., Sirchia, G \& Bellobono, A. 1997. Use of Photografting Technique for the Immobilization of Bloodgrouping Antibodies onto Microtiter Plates. J. Biomed. Mater. Res. 37: 566-572.

Aoyama, Y., Irwan, G. S., Kuroda, S., Kubota, H \& Kondo, T. 2001. Reactivity of Polymer Catalyst Prepared by Acrylic Acid-Grafted Polyethylene. Polymer Preprints, Japan, 50: 256.

Chan, C. M. 1994. Polymer Surface Modification and Characterization. Hanser/Gardner Publications, Inc., Cincinmati, p. 1-5.

Choi, S. H., Hwang, Y. M., Ryoo, J. J., Lee, K. P., Ohta, K., Takeuchi, T., Jin, J. Y \& Fujimoto, C. 2003. Surface Grafting of Glycidyl Methacrylate on Silica Gel and Polyethylene Beads. Electrophoresis. 24: 3181-3186.

Chun, H. J., Cho, S. C., Lee, Y. M., Lee, H. K., Suh, T. S \& Shinn, K. S. 1999. Graft Copolymerization of Mixtures of Acrylic Acid and Acrylamide onto Polypropylene Film. J. Appl. Polym. Sci. 72: 251-256.

Deng, J. P., Yang, W. T \& Rånby, B. 2000. Surface Photografting Polymerization of Vinyl Acetate (VAc), Maleic Anhydride, and Their Charge Transfer Complex. II. VAc(2). J. Appl. Polym. Sci. 77: 1522-1531.

El-Sayed, A. Hegazy, E. A.; El-Rehim, H. A. A.; Khalifa, N. A.; Atwa, S. M \& Shawky, H. A. 1997. Anionic/Cationic Membranes Obtained by a Radiation Grafting Method for Use in Waste Water Treatment. Polym. Int. 43: 321-332.

El-Sawy, N. M \& Sagheer, F. A. 2001. Radiation-Induced Graft Polymerization of Acrylic Acid onto Poly(tetrafluoroethyleneperflurovinyl ether) Copolymer Films: Complexation with Some Transition Metals and Bological Activity. Eur. Polym. J. 37: 161-166.

Guclu, G., Gurdag, G., \& Ozgumus, S. 2003. Competitive Removal of Heavy Metal lons by Cellulose Graft Copolymers J. Appl. Polym. Sci. 90: 2034-2039.

Hashimoto, K., Aoyama, Y., Irwan, G. S., Kuroda, S \& Kubota, H. 2003. Catalytic Reactivity of Polymer Catalyst Prepared by Photografting of Monomer Mixture Consisting of NIsopropylacrylamide. Polymer Preprints, Japan, 52: 277.

He, C \& Z. Gu. 2003. Studies on Acrylic Acid "rafted Polyester Fabrics by Electron Beam Preirradiation Method. I. Effects of Process Parameters on Graft Ratio and Characterization of Grafting. J. Appl. Polym. Sci. 89: 3931-3938.

Hegazy, E. A., Kamal, H., Khalifa, N. A \& Mahmoud, G. A. 2001. Separation and Extraction of Some Heavy and Toxic Metal Ions from Their Wastes by Grafted Membranes. J. Appl. Polym. Sci. 81: 849-860.

Huang, J., Wang, X., Chen, X \& Yu, X. 2003. TemperatureSensitive Membranes Prepared by the Plasma-Induced Graft Polymerization of Nisopropylacrylamide into Porous Polyethylene Membranes. J. Appl. Polym. Sci. 89: 3180 3187.

Irwan, G. S., Kuroda, S., Kondo, T \& Kubota, H. 2002a. Photografting of $\mathrm{N}$-Isopropylacrylamide on Polyethylene Film in Mixed Solvents Composed of Water and Organic Solvent. J. Appl. Polym. Sci. 87: 2454-2461.

Irwan, G. S., Kuroda, S., Kondo, T \& Kubota, H. 2002b. Photografting of Methacrylic Acid on Polyethylene Film: Effect of Mixed Solvents Consisting of Water and Organic Solvent. J. Appl. Polym. Sci. 83: 2454-2461.

Irwan, G. S., Kuroda, S., Kubota, H \& Kondo, T. 2004a. Characteristics of Acrylic Acid-Grafted Polyethylene Prepared by Photografting Using Mixed Solvent Consisting of Water and Organic Solvent. Eur. Polym. J. 40: 171-179. Irwan, G. S., Kuroda, S., Kubota, H \& Kondo, T. 2004b. Effect of Mixed Solvent Consisting of Water and Organic Solvent on Photografting of Glycidyl Methacrylate on Polyethylene Film. J. Appl. Polym. Sci. 93: 994-1000.

Irwan, G. S., Kuroda, S., Kubota, H \& Kondo, T. 2005b. Photografting of $\mathrm{N}$-isopropylacrylamide and Glycidyl Methacrylate Binary Monomers on Polyethylene Film: Effect of Mixed Solvent Consisting of Water and Organic Solvent on J. Appl. Polym. Sci. 97: 2469-2475.

Irwan, G. S., Kuroda, S., Kubota, H \& Kondo, T. 2005b. Photografting of $\mathrm{N}$-isopropylacrylamide and Glycidyl Methacrylate Binary Monomers on Polyethylene Film: Effect of Mixed Solvent Consisting of Water and Organic Solvent on J. Appl. Polym. Sci. 97: 2469-2475.

Irwan, G. S \& Wasinton, S. 2006a. Daya Absorbsi Polietilen Film Tergrafting Dengan Asam Metakrilat Terhadap Ion Logam. J. Sains Tek. FMIPA Unila. 12(3): 192-198.

Irwan, G. S. 2006b. Fungsionalisasi Polietilen Film Dengan Polimer Peka Suhu Dengan Metoda Fotografting. Seminar Nasional Kimia dan Kongres Nasional Himpunan Kimia Indonesia, Jakarta 22 Februari 2006, Hal. 27.

Irwan, G. S \& Wasinton, S. 2007. Reaktifitas Film Polietilen Tergrafting Glisidil Metakrilat Yang Diperoleh Dengan Metoda Fotografting. J. Sains Tek. SIGMA. 10(1): 35-44.

Islam, M. A.; A. Dimov \& Malinova. A. L. 1992. EnvironmentSensitive Properties of Polymethacrylic Acid-Grafted Polyethylene Membranes. J. Membr. Sci. 66: 69-78.

Kim, M., Saito, K., Furusaki, S., Sugo, T \& Okamoto, J. 1991. Water Flux and Protein Adsorption of a Hollow Fiber Modified with Hydroxyl Groups. J. Membr. Sci. 56: 289-302.

Koh, S. K., Song, S. K., Choi, W. K \& Jung, H. J. 1995. Improving Wettability of Polycarbonate and Adhesion with Aluminium by $\mathrm{Ar}^{+}$Ion Irradiation. J. Mater. Res. 10: 2390.

Kubota, H \& Shiobara, N. 1998. Photografting of $\mathrm{N}$ isopropylacrylamide on Cellulose and TemperatureResponsive Character of the Resulting Grafted Celluloses. Reactive \& Functional Polymers. 37: 219-224.

Leie, A. K., Devotta, I \& Masheikar, R. A. 1997. Predictions of Thermoreversible Volume Phase Transitions in Copolymer Gels by Lattice-Fluid-Hydrogen-Bond Theory. J. Chem. Phys. 106: 4768-4772.

Liu, W., Wang, Y. J \& Sun, Z. 2003. Effects of PolyethyleneGrafted Maleic Anhydride (PE-g-MA) on Thermal Properties, Morphology, and Tensile Properties of Low-Density Polyethylene (LDPE) and Corn Starch Blends. J. Appl. Polym. Sci. 88: 2904-2911.

Moad, G., Chiefari, J., Mayadunne, R. T. A., Moad, C. L., Postma, A., Rizzardo, E and Thang, S. H. 2002. Initiating Free Radical Polymerization. Macromol. Symp. 182: 65-80.

Pesneau, I., Champagne, M. F \& Huneault, M. A. 2004. Glycidyl Methacrylate Grafted Linear Low-Density Polyethylene Fabrication and Application for Polyester/ Polyethylene Bonding. J. Appl. Polym. Sci. 91: 3180-319.

Saito, N., Yamashita, S \& Matsuda, T. 1997. Laser-IrradiationInduced Surface Graft Polymerization Method. J. Polym. Sci. A: Polym. Chem. 35: 747-750.

Suh, T. S., Joo, C. K., Kim, Y. C., Lee, M. S., Lee, H. K., Choe, B. Y \& Chun, H. J. 2002. Surface Modification of Polymethyl Methacrylate Intraocular Lenses with the Mixture of Acrylic Acid and Acrylamide via Plasma-Induced Graft Copolymerization. J. Appl. Polym. Sci. 85: 2361-2366.

Tanaka, Y., Kagami, Y., Matsuda, A \& Osada, Y. 1995. Thermoreversible Transition of Tensile Modulus of Hydrogel with Ordered Aggregates. Macromolecules. 28: 2574-2576.

Virtanen J \& Tenhu H. 2001. GMA and NIPAAm copolymerization. J Polym Sci A Polym Chem. 39: 3716-3722.

Wang, H \& Brown, H. R. 2004. Ultraviolet Grafting of Methacrylic Acid and Acrylic Acid on High-Density Polyethylene in Different Solvents and the Wettability of Grafted HighDensity Polyethylene. I. Grafting. J. Polym. Sci. Part A: Polym. Chem. 42: 253-262. 
Yang, W \& Ranby, B. 1996. Bulk Surface Photografting Process and Its Applications. II. Principal Factors Affecting Surface Photografting. J. Appl. Polym. Sci. 62: 545-555.

Yu, J. J \& Ryu, S. H. 1999. Ultraviolet-Initiated Photografting of Glycidyl Methacrylate onto Styrene-Butadiene Rubber. J Appl. Polym. Sci. 73: 1733-1739.

Zhao, J. R., Feng, Y \& Chen, F. X. 2003. Modi.cation of Highly Chlorinated Polyethylene (HCPE) with Methyl Methacrylate by the Mechanochemistry Reaction. I. Synthesis and Characterization. J. Appl. Polym. Sci. 89: 811-816.

Zou, X. P., Kang E. T., Neoh, K. G., Zhang, Y., Tan, K. L., Cui, C. Q \& Lim, T. B. 2001. Plasma Polymerization and Deposition of Glycidyl Methacrylate on $\mathrm{Si}(100)$ Surface for Adhesion Improvement with Polymide" Polym. Adv. Technol. 12: 583595. 